\title{
Enhanced Device Performance via Interface Engineering in Polymer-based Optoelectronic Devices
}

\author{
Eui Dae Jung . Myoung Hoon SonG* \\ School of Materials Science and Engineering, Ulsan National Institute of Science and Technology, Ulsan 44919, Korea
}

Yun Seok NAM

MLCC Product Development 4 Group / Samsung Electro-Mechanics, Basun 46754, Korea

Bo Ram $\mathrm{LEE}^{\dagger}$

Department of Physics, Pukyong National University, Busan 48513, Korea

(Received 01 July 2021 : revised 26 July 2021 : accepted 30 July 2021)

\begin{abstract}
Achieving efficient electron transport is challenging owing to the large energy barrier between the conduction band of n-type metal oxide and the lowest unoccupied molecular orbital (LUMO) of the emissive layer in inverted polymer light-emitting diodes (PLEDs) or the active layer in inverted polymer solar cells (PSCs), which results in unbalanced charge transport, leading to low device efficiencies. Herein, we have demonstrated that the device performance could be enhanced in both PLEDs and PSCs by treating either the interface between the electron transport layer (ETL) and the emissive layer in PLEDs or the active layers with self-assembled dipole monolayer (SADM), ionic liquid molecules (ILM) and polar solvent (PS). The interface engineering results in a reduction of the energy barrier, which results in enhanced electron transport in both devices. Especially, optimized PLEDs and PSCs show an external quantum efficiency (EQE) of $1.38 \%$ and a power conversion efficiency (PCE) of $4.21 \%$, which are enhanced by approximately 138- and 1.37-fold, respectively, compared to the reference devices.
\end{abstract}

Keywords: Polymer light-emitting diodes, Polymer solar cells, Interface engineering, Surface treatment

\section{계면 조절을 통한 고분자 기반 광전자소자의 성능 향상}

\author{
정의대 · 송명훈* \\ 울산과학기술원 신소재공학과, 울산 44919, 대한민국 \\ 남윤석 \\ 삼성전기 MLCC 제품개발 $4 \mathrm{G}$, 부산 46754 , 대한민국 \\ 이보람 \\ 부경대학교 물리학과, 부산 48513 , 대한민국 \\ (2021년 7월 01일 받음, 2021년 7월 26일 수정본 받음, 2021년 7월 30 일 게재 확정)
}


역구조의 고분자 광전자소자는 산화아연, 산화티타늄 등 n-타입 금속 산화물의 전도대 와 발광소자에서 발광층 또는 태양전지에서 광활성층의 최저준위 비점유 분자궤도 사이에 존재하는 큰 에너지 장벽 때문에 전자 수송이 원활하게 이뤄지지 않아 불균형적인 전하 수송이 생기며 이는 결과적으로 낮은 소자 성능으로 이어진다. 따라서, 본 연구에서는 자기조립 쌍극자 분자, 이온성 액체 분자, 아민 기반의 극성 용매를 이용하여 전자수송층과 발광층 또는 광활성층 사이의 계면 조절을 통해 에너지 장벽을 낮춤으로써 효과적인 전자 수송을 유도하여 광전자 소자의 성능을 향상시켰다. 특히, 최적화 된 고분자 발광소자에서는 기준 소자보다 138 배 향상된 $1.35 \%$ 의 외부양자효율을 보여주며, 고분자 태양전지에서는 기준 소자보다 1.37 배 향상된 $4.21 \%$ 의 광 변환효율을 보여준다.

Keywords: 고분자 발광소자, 고분자 태양전지, 계면 조절, 표면 처리

\section{I. 서 론}

지난 수십년 동안 고분자 발광소자 (polymer lightemitting diodes, PLEDs), 고분자 태양전지 (polymer solar cells, PSCs) 와 같은 고분자 기반 광전자소자 (optoelectronic devices)는 저비용, 저온, 용액 공정 등 다양한 공정의 장점 뿐 아니라, 대면적화, 유연한 기계적 물성 등의 장점들로 인해 차세대 디스플레이와 친환경 에너지원의 후 보로서 많은 연구가 활발하게 진행되었다. [1-6]

광전자소자가 상용화 되기 위해서는 높은 소자 효율 (device efficiency) 과 우수한 소자 안정성 (device stability)이 뒷받침 되어야만 한다. 주로 많이 사용하는 p-i-n 구조 (conventional structure) 의 광전자소자는 전 극, 전하수송층, 발광소자의 발광층 (emissive layer) 또 는 태양전지의 광활성층 (active layer) 사이에서 원활 한 전하 수송을 통해 높은 소자 효율을 보여준다. 하 지만 일반적인 고분자 발광소자 또는 태양전지에서는 정공수송층 (hole transport layer, HTL)으로 $\operatorname{poly}(3,4-$ ethylenedioxylenethiophene):poly(styrenesulfonic acid) (PEDOT:PSS)와 같은 반응성 물질 (reactive material)을 주로 사용하는데 이는 하부 전극인 인듐 주석 산화물 (indium tin oxide, ITO) 을 부식시키고, 발광층 또는 광활성층 에 침투하여 소자의 안정성을 저하시킨다. $[7,8]$ 또한 칼슘 (calcium, Ca), 바륨 (barium, Ba), 알루미늄 (aluminum, $\mathrm{Al}$ ) 등과 같이 낮은 일함수 (work function) 를 갖는 금속 을 상부전극으로 사용하기 때문에 소자가 쉽게 산화되어 낮은 소자 안정성 초래한다는 연구들이 보고되었다. 따라 서, PEDOT:PSS 대신 전기적, 광학적 특성이 우수한 금속 산화물을 전하수송층으로 사용하고, 수분과 산소에 안정한 높은 일함수를 갖는 금속을 상부전극으로 사용하는 역구조 (inverted structure, n-i-p) 형태의 광전자소자가 우수한 소자 안정성을 보인다는 연구가 많이 보고되었다. [9-12]

*E-mail: mhsong@unist.ac.kr

${ }^{\dagger}$ E-mail: brlee@pknu.ac.kr
특히 정공수송층으로 주로 사용되는 산화몰리브덴 (molybdenum oxide, $\mathrm{MoO} 3$ ) 은 고분자 발광층 또는 활성 층의 최고준위 점유 분자궤도 (highest occupied molecular orbital level, $\mathrm{HOMO}$ )와 금 (gold, $\mathrm{Au}$ )과 은 (silver, $\mathrm{Ag}$ ) 과 같은 양극 (anode) 사이에 옴컨택 (ohmic contact)를 형성하여 효과적인 정공 수송을 제공한다. $[15,16]$ 하지 만 전자수송층 (electron transport layer, ETL)으로 주로 사용하는 산화아연 (zinc oxide, $\mathrm{ZnO}$ ), 산화티타늄 (titanium oxide, $\mathrm{TiOx}$ ) 등과 같은 n-타입 금속 산화물의 전도 대 (conduction band) 와 발광층 또는 광활성층의 최저준 위 비점유 분자궤도 (lowest unoccupied molecular orbital, LUMO) 사이에 존재하는 큰 에너지 장벽 (energy barrier) 때문에 전자 수송이 원활하게 이뤄지지 않아 불균형적인 전하 수송이 생기며 이는 결과적으로 낮은 소자 성능으로 이어진다. [13-19] 따라서, 본 연구에서는 자기조립 쌍극자 분자 (self-assembled dipole monolayer, $\mathrm{SADM}$ ), 이온성 액체 분자 (ionic liquid molecule, ILM), 아민 기반의 극성 용매 (polar solvent, PS) 를 이용하여 전자수송층 (electron transport layer, ETL) 과 발광층 또는 광활성층 사이의 계 면 조절 (interface engineering) 을 통해 에너지 장벽을 낮 춤으로써 효과적인 전자 수송을 유도하여 광전자 소자의 성능을 향상시켰다. 뿐만 아니라, 자기조립 쌍극자 분자, 이온성 액체 분자, 극성 용매를 계면층 (interfacial layer) 으로 사용하였을 때 나타나는 효과를 발광소자 및 태양전 지에서 비교 분석을 하였다.

\section{II. 실 험}

고분자 발광소자를 제작하기 위해서 먼저 음극으로 사용 되는 Indium tin oxide (ITO) 기판(15 $\Omega / \mathrm{sq}, \mathrm{AMG}$ )을 세제 로 세척후 증류수, acetone, isopropanol에 넣고 각각 10 분 씩 초음파 세척을 하였다. 오븐에서 건조 후에 UV-ozone 처 리를 30 분간 진행한 후 전자수송층으로 $\mathrm{ZnO}$ 를 형성하기 위 
해 zinc acetate dihydrate를 같은 몰 비율의 ethanolamine 과 함께 2-methoxyethanol에 $0.75 \mathrm{M}$ 농도로 녹인 용액 을 $3000 \mathrm{rpm}$ 으로 40 초 동안 스핀코팅을 한 후에 $400{ }^{\circ} \mathrm{C}$ 에서 1 시간동안 열처리를 하였다. 계면 처리시 $\mathrm{SADM}$ 은 4-Methoxybenzoic acid (BA-OCH3, Sigma-Aldrich) 를 $7 \mathrm{mM}$ 농도로 ethanol에 녹여 $3000 \mathrm{rpm}$ 으로 40 초 동안 스핀코팅하였다. ILM은 1-benzyl-3-methylimidazolium chloride (benmim-Cl, Sigma-Aldrich) 를 $0.1 \mathrm{wt} \%$ 농도 로 물에 녹여 $5000 \mathrm{rpm}$ 으로 스핀코팅을 한 후에 $120{ }^{\circ} \mathrm{C}$ 에 10 분간 열처리하였다. PS의 경우 ethanolamine을 2methoxyethanol에 1:20 의 부피 비율로 희석한 용액을 사 용하였으며 $70{ }^{\circ} \mathrm{C}$ 의 온도의 용액을 $3000 \mathrm{rpm}$ 으로 스핀코 팅한 후 $120{ }^{\circ} \mathrm{C}$ 에 10 분간 열처리하였다. 발광층으로 SPB$02 \mathrm{~T}$ (Merck) 물질을 $6.5 \mathrm{mg} / \mathrm{ml}$ 농도로 chlorobenzene에 녹여 $2000 \mathrm{rpm}$ 으로 45 초 동안 스핀코팅 하였다. 마지막 으로 정공주입층 및 양극 전극을 형성하기 위해 $10 \mathrm{~nm}$ 의 산화몰리브덴 (MoO3, 태원과학) 과 $100 \mathrm{~nm}$ 의 금을 열증착 기를 이용하여 증착하였다.

고분자 태양전지 제작은 위의 고분자 발광소자 제작에 서 발광층과 상부 금 전극을 제외하고 대부분 동일하였다. $\mathrm{ZnO}$ 의 경우 $0.5 \mathrm{M}$ 농도의 zinc acetate dihydrate 용액을 사용하였다. 활성층으로 P3HT:PC60BM (무게비 10:8)을 $\mathrm{P} 3 \mathrm{HT}$ 에 대해 $2 \mathrm{wt} \%$ 농도로 무수 chlorobenzene에 같이 녹였고 $80^{\circ} \mathrm{C}$ 에 24 시간동안 강렬히 저어 용액을 준비하였 다. 이를 $0.2 \mathrm{~m}$ 소수성 $\mathrm{PTFE}$ 필터에 걸러 $900 \mathrm{rpm}$ 으로 1 분간 스핀코팅하고 $150{ }^{\circ} \mathrm{C}$ 에 10 분간 열처리하였다. 마지 막으로 정공주입층 및 양극 전극을 형성하기 위해 $5 \mathrm{~nm}$ 의 $\mathrm{MoO} 3$ 와 $100 \mathrm{~nm}$ 의 은을 열증착기를 이용하여 증착하였다.

고분자 발광소자의 특성 분석을 위해서 Keithley사, 2400

Source Measure Unit과 Konica Minolta사, CS-2000 분광 방사휘도계를 연동하여 전류밀도-전압-휘도 $(J-V-L)$ 특성 을 동시에 측정하였다. 램버시안 방출 프로파일 (Lambertian emission profile) 을 가정하여 전계 발광 외부양자효 율 (electroluminescent external quantum efficiency, EL$\mathrm{EQE})$ 을 계산하였다. 고분자 태양전지의 특성 분석을 위해 서 Peccell Technology사, PEC-L01 모의태양광원을 통한 $\mathrm{AM} 1.5 \mathrm{G} 100 \mathrm{~mW} / \mathrm{cm} 2$ 환경에서 Ivium사, IviumStat 일 정전위기를 통해 전류밀도-전압 $(\mathrm{J}-\mathrm{V})$ 특성을 측정하였다. 소자 면적은 $13.5 \mathrm{~mm}^{2}$ 였으며, 장치는 테스트 전에 에폭시 와 유리로 봉지 (encapsulation) 하였다. 입사 광자 대 전자 변환 효율은 PV measurement사, QEX7을 통해 측정하였 고 Impedance 측정은 Ivium사, IviumStat 일정전위기를 통해 측정하였다.
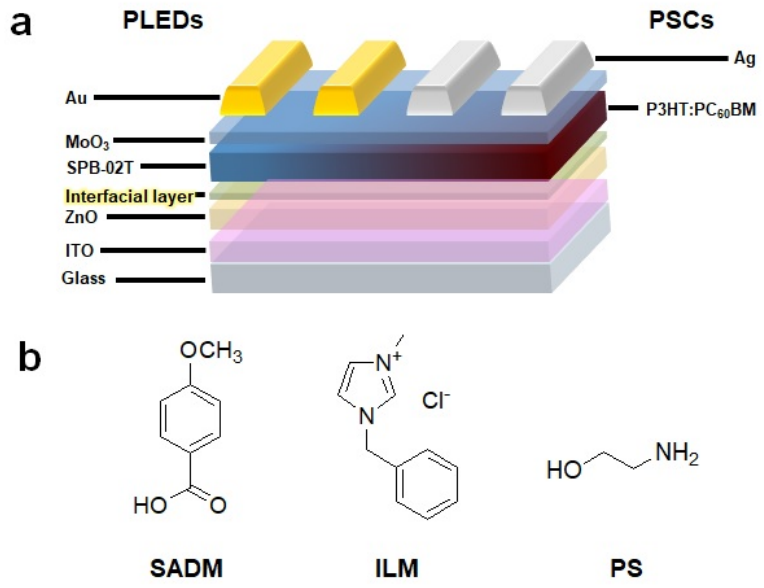

Fig. 1. (Color online) (a) Schematic of PLEDs and PSCs device structures, (b) the chemical structures of interfacial layers; SADM, ILM and PS.

\section{III. 결과 및 논의}

본 실험에서 사용된 (a) 고분자 발광소자 (ITO / $\mathrm{ZnO}$ / interfacial layer / SPB-02T / MoO3 / Au) 및 태양전 지 (ITO / ZnO / interfacial layer / P3HT:PC60BM / $\mathrm{MoO} 3 / \mathrm{Ag}$ ) 구조와 (b) 계면층으로 사용된 자기조립 쌍 극자 분자, 이온성 액체 분자, 극성 용매의 화학적 구조가 Fig. 1에 나타나 있다. ITO는 음극으로, $\mathrm{ZnO}$ 는 전자수 송층으로, $\mathrm{SADM}, \mathrm{ILM}, \mathrm{PS}$ 는 각각 계면층 비교군으로, SPB-02T는 발광소자에서 발광층으로, P3HT:PC60BM는 태양전지에서 광활성층으로, $\mathrm{MoO} 3$ 는 정공수송층으로, $\mathrm{Au}$ 와 $\mathrm{Ag}$ 는 각각 발광소자와 태양전지에서 음극으로 사용하 였다. 전자 공여 그룹 (electron-donating group)을 포함하 는 음극 쌍극자 (negative dipoles) 로 구성된 카르복실 산 (carboxylic acid) 기반 $\mathrm{SADM}\left(\mathrm{BA}-\mathrm{OCH}_{3}\right)$ 은 하이드록실 (hydroxyl) - $\mathrm{OH}$ 말단기를 갖는 금속 산화물과 잘 결합할 수 있는 분자구조이다. 이온성 액체 분자는 1-벤질-3-메 틸이미다 졸륨 (1-benzyl-3-methylimidazolium) 의 양이온 (cationic) 과 염화물 음이온 (anionic)으로 구성되어져 있 다. 아민 기반의 극성용매는 하이드록실 그룹과 아민 그룹 이 말단기를 갖는 에탄올 아민 (ethanolamine, EA)을 2메톡시에탄올 (2-methoxyethanol, 2-ME)에 희석시켜 사 용하였다. 각 계면층들의 정확한 두께는 측정이 어렵지만 모두 $5 \mathrm{~nm}$ 이하의 얇은 두께로 알려져 있고 본 실험에서는 계면층들 모두 비슷한 얇은 두께에서 계면층들간 비교를 하여 두께 차이에 따른 영향을 최소화하였다. [16-18]

Figure 2는 계면층 유무와 종류에 따라 변화한 고분자 발광소자의 소자 특성을 보여준다. 이는 (a) 전류 밀도 대 전압 $(J-V),(\mathrm{b})$ 휘도 대 전압 $(L-V),(\mathrm{c})$ 발광효율 대 전 
압 $(L E-V),(\mathrm{d})$ 외부양자효율 대 전압 $(E Q E-V)$ 를 포함 하고 있다. 계면층이 없는 발광소자 (기준 소자, reference device) 의 경우에는 계면층이 존재하는 발광소자에 비해 턴온 전압 (turn-on voltage) 이 $6.8 \mathrm{~V}$ 로 가장 높았다. 이 는 $\mathrm{ZnO}$ 와 발광층 사이의 큰 에너지 장벽으로 인해 전자 주입이 어렵게 되어 정공과 전자의 불균형적인 전하 주입 으로부터 기인한 것으로 여겨진다. 결과적으로 기준 발광 소자에서는 재결합 (recombination)이 가장 높은 전압에 서 일어나며 휘도가 $60 \mathrm{~cd} / \mathrm{m}^{2}$, 외부양자효율이 $0.01 \%$ 로 가장 좋지 못한 소자효율을 보여주었다. 반면에 계면층을 도입한 발광소자들은 $\mathrm{ZnO}$ 와 발광층 사이에 존재하는 에 너지 장벽을 줄여줌으로써 기준 발광소자보다 전자 주입을 원활하게 하여 소자효율을 향상시킬 수 있었다. SADM을 이용한 발광소자는 $940 \mathrm{~cd} / \mathrm{m}^{2}$ 의 휘도, $0.05 \%$ 의 외부양자 효율을 보여주고, ILM을 이용한 발광소자는 $800 \mathrm{~cd} / \mathrm{m}^{2}$ 의 휘도, $0.12 \%$ 의 외부양자효율을 보여주고, $\mathrm{PS}$ 를 이용한 발광소자는 $2300 \mathrm{~cd} / \mathrm{m}^{2}$ 의 휘도, $1.38 \%$ 의 외부양자효율을 보여주었다. 턴온전압은 SADM $(6.4 \mathrm{~V})$, ILM $(4.1 \mathrm{~V})$, PS $(3.1 \mathrm{~V})$ 순으로 나타났다. 발광소자 특성을 비교해 본 결과 $\mathrm{ZnO}$ 와 발광층 사이의 에너지 장벽이 $\mathrm{PS}$ 를 사용했을 때 가장 많이 줄어 들었고, $\mathrm{ILM}$ 을 사용했을 때가 그 다음, $\mathrm{SADM}$ 을 사용했을 때가 가장 적게 줄어 들었음을 예상할 수 있었다. 특히 PS를 사용했을 때는 용액공정으로 만들 어진 $\mathrm{ZnO}$ 표면에 존재하는 표면 결함 (surface defect)를 크게 줄임으로써 누설전류 (leakage current)를 감소시켜 극적인 소자효율 향상을 이끌 수 있었다. 계면층을 도입 유무에 따른 발광소자 특성 결과를 정리한 표를 Table 1 에서 볼 수 있다.

Figure 3 은 계면층 유무와 종류에 따라 변화한 고분자 태양전지의 소자 특성을 보여준다. (a) 전류 밀도-전압 $(J-V)$ 특성과 (b) $E Q E$ 특성을 $1000 \mathrm{~W} / \mathrm{m}^{2} \mathrm{AM} 1.5 \mathrm{G}$ 조도 (illumination)에서 측정하였다. 계면층이 없는 태양 전지 (기준 소자, reference device) 의 경우에는 계면층이 존재하는 태양전지에 비해 단락전류 (short circuit current, $\mathrm{Jsc}$ ), 충전율 (fill factor, $\mathrm{FF}$ ), 광변환효율 (PCE) 가 크게 향상되었다. 이는 발광소자와 마찬가지로 $\mathrm{ZnO}$ 와 광활성 층 사이의 에너지 장벽이 줄어듬으로써 효과적인 전자 수 송이 가능해졌기 때문이라 판단된다. 기준 태양전지에서 는 가장 낮은 단락전류 $\left(8.67 \mathrm{~mA} / \mathrm{cm}^{2}\right)$, 충전율 $(0.62)$, 광 변환효율 $(3.06 \%)$ 을 나타냈지만 계면층을 도입한 태양전 지들은 이보다 우수한 소자 특성을 보였다. 이 중 $\mathrm{SADM}$ 을 이용한 태양전지는 $10.26 \mathrm{~mA} / \mathrm{cm} 2$ 의 단락전류, 0.62 의 충전율, $3.63 \%$ 의 광변환효율을 보여주고, ILM을 이용한 태양전지는 $10.46 \mathrm{~mA} / \mathrm{cm}^{2}$ 의 단락전류, 0.63 의 충전율, $3.76 \%$ 의 광변환효율을 보여주고, PS를 이용한 태양전지는
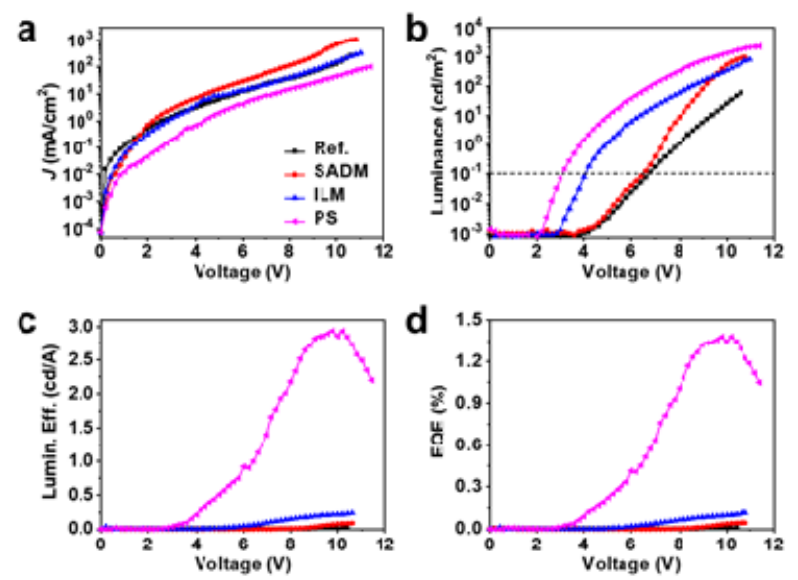

Fig. 2. (Color online) Device characterization of PLEDs with and without the interfacial layer; (a) current density versus applied voltage $(J-V)$ characteristics, (b) luminance versus applied voltage $(L-V)$, (c) luminous efficiency versus applied voltage $(L E-V)$ and (d) external quantum efficiency versus applied voltage $(E Q E-V)$.
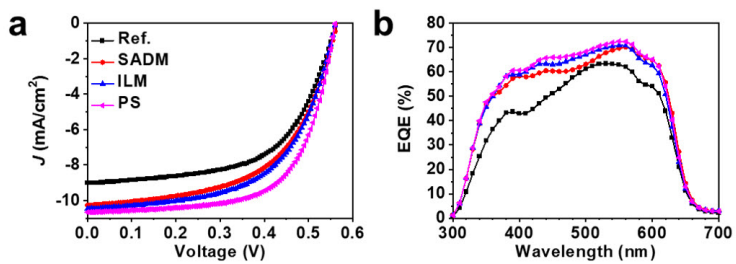

Fig. 3. (Color online) Device characterization of PSCs with and without the interfacial layer; (a) $J-V$ characteristics (a) and EQE characteristic (b) under $1000 \mathrm{~W} / \mathrm{m}^{2}$ AM 1.5G illumination.

$10.70 \mathrm{~mA} / \mathrm{cm}^{2}$ 의 단락전류, 0.69 의 충전율, $4.21 \%$ 의 광변 환효율을 보여주었다. P3HT:PC60BM와 같은 벌크 이종 접합 (bulk heterojunction) 에서의 개방전압 (open circuit voltage, Voc)은 P3HT와 같은 전자 주개인 도너 (donor) 의 $\mathrm{HOMO}$ 레벨과 $\mathrm{PC} 60 \mathrm{BM}$ 과 같은 전자 받개인 억셉터 (acceptor) 의 LUMO 레벨 사이의 차이값으로 결정되어지 기 때문에 기준소자 및 $\mathrm{SADM}, \mathrm{ILM}, \mathrm{PS}$ 를 이용한 태양전 지 모두 $0.57 \mathrm{~V}$ 로 같았다. 태양전지 특성을 비교해 본 결 과 $\mathrm{PS}$ 를 사용했을 때 발광소자와 마찬가지로 가장 향상된 소자특성을 보였고, ILM을 사용했을 때가 그 다음, $\mathrm{SADM}$ 을 사용했을 때가 가장 적게 향상 되었음을 알 수 있었다. 특히 PS를 사용했을 때는 단락전류와 충전율이 크게 향상 되어 극적인 소자효율 향상을 이끌 수 있었다. 태양전지의 소자특성 결과를 정리한 표는 Table 2 에서 볼 수 있다.

위에 나타낸 결과를 분석해보면, 최적화 된 고분자 발광 소자에서는 기준 소자보다 138 배 향상된 외부양자효율을 보여주며, 고분자 태양전지에서는 기준 소자보다 1.37 배 향상된 광 변환효율을 보여준다. 
Table 1. Summary of PLEDs with and without interfacial layers.

\begin{tabular}{ccccc}
\hline \hline Devices configuration & $\begin{array}{c}L_{\max }\left[\mathrm{cd} / \mathrm{m}^{2}\right] \\
\text { @ bias }\end{array}$ & $\begin{array}{c}L E_{\max }[\mathrm{cd} / \mathrm{A}] \\
@ \text { bias }\end{array}$ & $\begin{array}{c}E Q E_{\max }[\%] \\
\text { @ bias }\end{array}$ & $\begin{array}{c}\text { Turn-on } \\
\text { Voltage }[\mathrm{V}] \\
\text { @ } 0.1 \mathrm{~cd} / \mathrm{m}^{2}\end{array}$ \\
\hline Reference device & $60[10.6 \mathrm{~V}]$ & $0.02[10.4 \mathrm{~V}]$ & $0.01[10.4 \mathrm{~V}]$ & 6.8 \\
SADM & $940[10.8 \mathrm{~V}]$ & $0.10[10.6 \mathrm{~V}]$ & $0.05[10.8 \mathrm{~V}]$ & 6.4 \\
ILM & $800[11.0 \mathrm{~V}]$ & $0.24[10.6 \mathrm{~V}]$ & $0.12[10.8 \mathrm{~V}]$ & 4.1 \\
PS & $2300[11.8 \mathrm{~V}]$ & $2.94[9.8 \mathrm{~V}]$ & $1.38[9.8 \mathrm{~V}]$ & 3.1 \\
\hline \hline
\end{tabular}

Full devices: ITO / ZnO / Interfacial layer / SPB-02T / $\mathrm{MoO}_{3} / \mathrm{Au}$

Table 2. Summary of PLEDs with and without interfacial layers.

\begin{tabular}{cccccc}
\hline \hline Devices configuration & $\begin{array}{c}J_{s c} \\
{\left[\mathrm{~mA} / \mathrm{cm}^{2}\right]}\end{array}$ & $\begin{array}{c}V_{o c} \\
{[\mathrm{~V}]}\end{array}$ & $\mathrm{FF}$ & $\begin{array}{c}\eta \\
{[\%]}\end{array}$ & $\begin{array}{c}J_{s c}(\mathrm{calc}) \\
{\left[\mathrm{mA} / \mathrm{cm}^{2}\right]}\end{array}$ \\
\hline Reference device & 8.67 & 0.57 & 0.62 & 3.06 & 8.81 \\
SADM & 10.26 & 0.57 & 0.62 & 3.63 & 10.25 \\
ILM & 10.46 & 0.57 & 0.63 & 3.76 & 10.41 \\
PS & 10.70 & 0.57 & 0.69 & 4.21 & 10.66 \\
\hline \hline
\end{tabular}

Full devices: ITO / ZnO / Interfacial layer /

$\mathrm{P} 3 \mathrm{HT}: \mathrm{PC}_{60} \mathrm{BM} / \mathrm{MoO}_{3} / \mathrm{Ag}$

Figure 4(a)는 P3HT:PC60BM와 같은 벌크 이종접합이 아닌 $\mathrm{P} 3 \mathrm{HT}$ 를 도너로 $\mathrm{ZnO}$ 를 어셉터로 사용하는 이중층 (bilayer) 형태의 태양전지 구조 (ITO / ZnO / interfacial layer / P3HT / $\mathrm{MoO}_{3} / \mathrm{Ag}$ ) 에서의 계면층 존재 유무에 따른 전류 밀도 특성을 보여준다. 이와 같은 구조는 $\mathrm{ZnO}$ 의 전도대에 따라 개방전압이 달라지는 구조이기 때문에 $\mathrm{ZnO}$ 위에 존재하는 계면층 종류에 따라 $\mathrm{ZnO}$ 와 발광층 또 는 광활성층 사이 계면에 존재하는 에너지 장벽의 변화를 관찰할 수 있다. 계면층이 없는 기준 소자는 $0.24 \mathrm{~V}, \mathrm{SADM}$ 을 이용한 태양전지는 $0.35 \mathrm{~V}, \mathrm{ILM}$ 을 이용한 태양전지는 $0.48 \mathrm{~V}$ 를, PS를 이용한 태양전지는 $0.50 \mathrm{~V}$ 의 개방전압을 보여줬다. 이는 계면층을 사용하였을 때 계면층의 분자들이 음극 쌍극자 형태를 형성하기 때문에 $\mathrm{ZnO}$ 의 전도대가 진공 레벨 (Vacuum level) 근처로 올라가 개방 전압의 증가를 초 래한다. 특히 PS를 사용한 태양전지에서는 2 배 이상 증가된 개방 전압을 보이며 이는 $\mathrm{ZnO}$ 와 발광층 또는 광활성층 사 이에 존재하는 에너지 장벽을 줄임으로써 균형적인 전하 수 송을 통해 발광소자와 태양전지에서 소자효율을 향상시킨 근거로 여겨진다. Figure $4(\mathrm{~b})$ 는 계면층 유무에 따른 $\mathrm{ZnO}$ 의 전도대의 변화를 플랫 밴드 조건에 대한 에너지 밴드 다 이어그램으로 보여준다. 계면층들은 분자구조 (molecular structure) 에 따라 스스로 친수성 (hydrophilicity) 부분은 $\mathrm{ZnO}$ 표면에 결합하려고 하고 소수성 (hydrophobicity) 부 분은 고분자 표면에 결합하고자 하기 때문에 자연스럽게 쌍극자 모멘트 (dipole moment)가 형성된다. [13,16-19] a
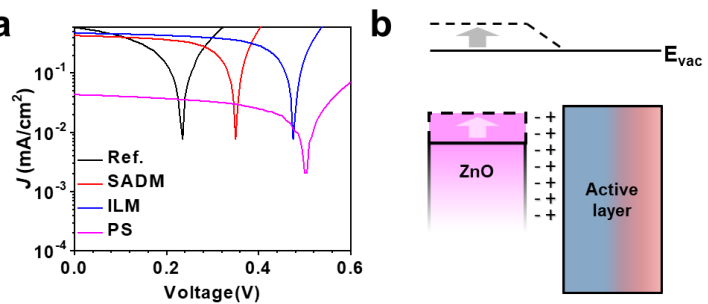

Fig. 4. (Color online) (a) $J-V$ characteristics of bilayer PSCs with and without the interfacial layers and (b) schematic energy diagrams for flat band conditions of $\mathrm{ZnO}$ / interfacial layer / active layer.
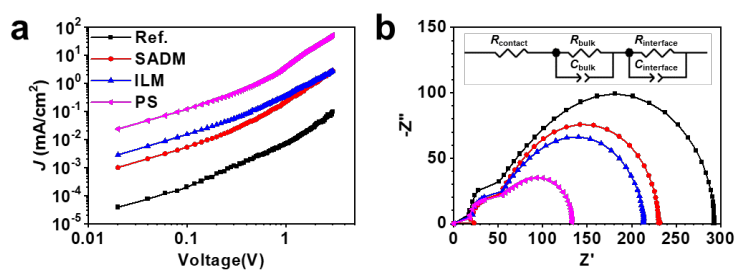

Fig. 5. (Color online) (a) Electron-only devices characteristic of ITO / ZnO/ interfacial layer / SPB-02T / $\mathrm{LiF} / \mathrm{Al}$ and (b) electrical impedance measurements for P3HT:PC ${ }_{60} \mathrm{BM}$ PSCs with and without the interfacial layer. The plots are fitted by an equivalent circuit.

따라서, $\mathrm{ZnO}$ 와 광활성층 사이에 계면층들은 분자구조의 전기음성도 (electronegativity) 차이에 따라 음극 쌍극자 모멘트를 형성함으로써 $\mathrm{ZnO}$ 의 전도대를 진공 레벨 쪽으로 변화 시킬 수 있음을 보여준다.

Figure $5(\mathrm{a})$ 는 $\mathrm{ZnO}$ 와 발광층 사이에 줄어든 에너지 장 벽으로부터 얼마만큼 전자 수송이 효과적으로 향상되었 는지 확인하기 위해 전자 주입만 가능한 소자 (electrononly device, ITO / ZnO/ interfacial layer / SPB-02T / $\mathrm{LiF} / \mathrm{Al}$ ) 를 제작하여 Mott-Gurney space-charge-limited current (SCLC) 방정식을 통하여 전자 이동도 (electron mobility) 를 계산하였다.

$$
J=\frac{9}{8} \mu_{\mathrm{eff}} \varepsilon_{0} \varepsilon_{r} \frac{V^{2}}{d^{3}}
$$

$J$ 는 전류밀도, $\mu_{\mathrm{eff}}$ 는 유효 전하 운반자 이동도 (effective 
Table 3. Summary of fitted parameters obtained from electrical impedance measurements for PSCs with and without interfacial layers.

\begin{tabular}{cccccc}
\hline \hline \multirow{2}{*}{ Devices configuration } & $\begin{array}{c}R_{\text {contact }} \\
{\left[\Omega \cdot \mathrm{cm}^{2}\right]}\end{array}$ & $\begin{array}{c}R_{\text {bulk }} \\
{\left[\Omega \cdot \mathrm{cm}^{2}\right]}\end{array}$ & $\begin{array}{c}C_{\text {bulk }} \\
{[\mathrm{nF}]}\end{array}$ & $\begin{array}{c}R_{\text {interface }} \\
{\left[\Omega \cdot \mathrm{cm}^{2}\right]}\end{array}$ & $\begin{array}{c}C_{\text {interface }} \\
{[\mathrm{nF}]}\end{array}$ \\
\hline Reference device & 21.2 & 82.6 & 0.66 & 307.0 & 434 \\
SADM & 22.8 & 47.6 & 1.92 & 243.0 & 900 \\
ILM & 23.0 & 52.4 & 0.99 & 227.3 & 1580 \\
PS & 19.9 & 45.4 & 2.52 & 143.7 & 2880 \\
\hline \hline
\end{tabular}

Full devices: ITO / ZnO / Interfacial layer / $\mathrm{P} 3 \mathrm{HT}: \mathrm{PC}_{60} \mathrm{BM} / \mathrm{MoO}_{3} / \mathrm{Ag}$

charge carrier mobility), $\varepsilon_{0}$ 는 자유공간의 유전율 (permittivity of free space), $\varepsilon_{r}$ 은 매질의 상대적인 유전율 (relative permittivity of the medium), $V$ 는 인가 전압, $d$ 는 발광층 의 두께이다. 계면층 유무에 따라 전자의 이동도를 계산한 결과, 기준 소자는 $1.75 \times 10^{-7} \mathrm{~cm}^{2} / \mathrm{V} \cdot \mathrm{s}, \mathrm{SADM}$ 을 사용 한 소자는 $5.56 \times 10^{-6} \mathrm{~cm}^{2} / \mathrm{V} \cdot \mathrm{s}, \mathrm{ILM}$ 을 사용한 소자는 $8.83 \times 10^{-6} \mathrm{~cm}^{2} / \mathrm{V} \cdot \mathrm{s}, \mathrm{PS}$ 를 사용한 소자는 $9.91 \times 10^{-5}$ $\mathrm{cm}^{2} / \mathrm{V} \cdot \mathrm{s}$ 을 보였다. 이는 계면층을 사용하였을 때 전자 수 송이 극적으로 향상됨을 증명한다. 결과적으로 발광소자나 태양전지에서 소자효율이 향상된 이유와 일치하며 본 연구 팀이 제안한 결과와 일치한다. Figure 5(b)는 계면층 사용 유무에 따른 태양전지에서 임피던스를 통한 저항 분석을 보 여준다. 계면층을 사용하였을 때 계면 저항값이 계면층을 사용하지 않았을 때와 비교하여 상대적으로 크게 감소하며 이는 단락전류의 증가와 충전율 향상에 영향을 준다. 특히 전자 이동도의 증가와 계면 저항의 감소는 발광소자와 태 양전지에서 보여주는 소자효율 증가와 일맥상통한 결과를 보인다.

\section{IV. 결 론}

본 연구에서는 $\mathrm{SADM}, \mathrm{ILM}, \mathrm{PS}$ 와 같은 계면층을 전자 수송층인 $\mathrm{ZnO}$ 와 발광층 또는 광활성층 사이에 도입하여 고분자 기반의 역구조 발광소자와 태양전지에서 전자의 수 송을 원활하게 하고 계면 저항을 줄임으로써 소자 효율을 향상시켰다. 계면층은 분자구조의 형태에 따라 자발적으로 음극 쌍극자 모멘트를 형성함으로써 전자수송층인 $\mathrm{ZnO}$ 의 전도대를 진공 레벨 방향으로 변화시켜 $\mathrm{ZnO}$ 와 발광층 또 는 광활성층 사이에 존재하는 큰 에너지 장벽 및 불일치를 감소시킬 수 있었다. 특히, PS 계면층을 사용해 최적화 된 고분자 발광소자에서는 기준 소자 $(0.01 \%)$ 보다 138 배 향상된 $1.38 \%$ 의 외부양자효율과 대략 38 배 향상된 2300 $\mathrm{cd} / \mathrm{m}^{2}$ 의 휘도를 보였으며, 고분자 태양전지에서는 기준
소자보다 대략 1.23 배 향상된 단락전류, 1.11 배 향상된 충 진율과 함께 기준 소자 $(3.06 \%)$ 보다 1.37 배 향상된 $4.21 \%$ 의 광변환효율을 보였다. 따라서, 역구조 고분자 발광소자 와 태양전지에서 전자수송층과 발광층 또는 광활성층 사 이에서 발생하는 불균형적인 전하 수송을 해결하기 위해서 적절한 계면층 사용을 통해 계면 저항을 감소시키고 전자 수송 능력을 향상시키는 것이 소자 효율 향상에 중요함을 알 수 있으며 또한 SADM, ILM, PS와 같은 간단한 계면층 도입은 페로브스카이트 발광소자나 태양전지, 레이저 소자, 트랜지스터 등 다양한 소자에 적용이 가능할 것으로 보인다.

\section{감사의 글}

본 논문은 부경대학교 자율창의학술연구비 $(2019, \mathrm{BR}$ Lee)에 의해 연구되었습니다.

\section{REFERENCES}

[1] J. H. Burroughes et al., Nature 347, 539 (1990).

[2] R. H. Friend et al., Nature 397, 121 (1999).

[3] B. R. Lee et al., J. Mater. Chem. 22, 21481 (2012).

[4] G. Yu et al., Science 270, 1789 (1995).

[5] J. Y. Kim et al., Science 317, 222 (2007).

[6] S.-J. Ko et al., Energy Environ. Sci. 6, 1949 (2013).

[7] Y.-H. Kim, S.-H. Lee, J. Noh and S.-H. Han, Thin Solid Films 510, 305 (2006).

[8] B. R. Lee et al., ACS Nano 6, 2984 (2012).

[9] K. Lee et al., Adv. Mater. 19, 2445 (2007).

[10] B. R. Lee et al., Adv. Mater. 27, 3553 (2015).

[11] K. Morii and M. Ishida, Appl. Phys. Lett. 89, 183510 (2006).

[12] D. Kabra et al., Adv. Mater. 20, 3447 (2008).

[13] J. S. Park et al., Appl. Phys. Lett. 96, 243306 (2010).

[14] J. S. Park et al., Appl. Phys. Lett. 99, 163305 (2011).

[15] H. Choi et al., Adv. Mater. 23, 2759 (2011).

[16] B. R. Lee et al., J. Mater. Chem. 21, 2051 (2011).

[17] B. R. Lee et al., Nat. Commun. 5, 5840 (2014).

[18] B. R. Lee et al., Adv. Mater. 26, 494 (2014).

[19] Y.-H. Kim, et al., Adv. Funct. Mater. 24, 3808 (2014). 